Research article

\title{
THE EFFECTS OF A PHYTOGENIC ADDITIVE ON THE HISTOMORPHOMETRIC CHARACTERISTICS OF THE INTESTINES IN WEANED PIGS WITH A SUBCLINICAL NATURAL INFECTION WITH Lawsonia intracellularis
}

\author{
DRAŠKOVIĆ Vladimir ${ }^{1}$, STANIMIROVIĆ Zoran ${ }^{2 *}$, GLIŠIĆ Milica ${ }^{3}$, \\ BOŠNJAK-NEUMULLER Jasna ${ }^{4}$, TEODOROVIĆ Radislava ${ }^{1}$, \\ TEODOROVIĆ Vlado ${ }^{3}$, KUKOLJ Vladimir ${ }^{5}$
}

\begin{abstract}
${ }^{1}$ Department of Animal Hygiene, Faculty of Veterinary Medicine, University of Belgrade, Bul. oslobodjenja 18, 11000 Belgrade, Serbia; ${ }^{2}$ Department of Biology, Faculty of Veterinary Medicine, University of Belgrade, Bul. oslobodjenja 18, 11000 Belgrade, Serbia; ${ }^{3}$ Department of Food Hygiene and Technology, Faculty of Veterinary Medicine, University of Belgrade, Bul. oslobodjenja 18, 11000 Belgrade, Serbia; ${ }^{4}$ Patent Co. DOO, Vlade Ćetkovića 1a, 24211 Mišićevo, Serbia; ${ }^{5}$ Department of Veterinary Pathology, Faculty of Veterinary Medicine, University of Belgrade, Bul. oslobodjenja 18, 11000 Belgrade, Serbia
\end{abstract}

(Received 04 February, Accepted 03 March 2020)

Proliferative enteropathy, also known as proliferative ileitis, is considered to be one of the most economically important diseases in pig production worldwide. The estimated losses per affected growing pig usually range from US $\$ 1$ to $\$ 5$. The disease is caused by Lawsonia intracellularis, a Gram-negative, obligately intracellular bacterium. Control of the disease can be achieved with the use of vaccines or antibiotics. Recently there has been an increase in the efforts in the control of certain pathologies of the digestive system with phytogenic additives. The aim of this work was to assess the effects of a phytogenic additive on the histomorphometric characteristics of the intestines in weaned pigs with a subclinical infection with $L$. intracellularis acquired spontaneously. Histomorphometry analysis showed that crypt depth was significantly shorter $(\mathrm{P}<0.05)$, and the villus-height-to-crypt-depth ratio $(\mathrm{P}<0.05)$ significantly greater in the treatment group than the control. This improvement in the histological parameters of the intestine, considered to be indicators of its health, proved the positive effect of the tested additive on the digestive system in pigs.

Key words: proliferative enteropathy, Lawsonia intracellularis, phytogenic feed additive, histomorphometry

\section{INTRODUCTION}

Proliferative enteropathy (PE), also referred to as proliferative ileitis, is one of the most economically important enteric diseases in pig production all over the world $[1,2]$. Total losses due to PE are estimated from US $\$ 1$ to $\$ 5$ per affected growing pig,

\footnotetext{
*Corresponding author: e-mail: zoran@vet.bg.ac.rs
} 
but are probably higher because the estimates are based only on clinical cases of the disease and do not involve subclinical ailments [3-6]. It is characterized by epithelial cell proliferation and hyperplasia leading to thickening of the intestinal mucosa of the ileum, but the jejunum and colon can also be affected [1,7]. The affected animals show clinical signs such as anorexia, diarrhoea, reduced growth, and decreased food conversion, but occasional sudden deaths may occur. It is well known that pigs can also be infected subclinically $[1,8,9]$.

PE is caused by the flagellated Gram-negative obligate intracellular bacterium named Lawsonia intracellularis [1]. L. intracellularis is transmitted in the pig population by the faecal-oral route, and also through contaminated equipment, insects or rodents [1012]. The bacteria can remain viable in the faeces at temperatures ranging from $5^{\circ} \mathrm{C}$ to $15^{\circ} \mathrm{C}$ for up to 2 weeks [10].

The control of $L$. intracellularis infection includes vaccination and antimicrobial therapy, for example with tiamulin, tylosin, tetracycline, lincomycin or some other antibiotics $[1,13]$. Subtherapeutic uses of antibiotics in animal feeds have been a part of pig production for more than 70 years [14].

However, the use of antibiotics leads to the potential development of resistant bacteria, leading to risk for animal and human health [15]. Therefore, antibiotic resistance is an important global public health challenge. In recent years, more frequently some alternatives have been opted for the use of phytogenic feed additives for the control of bacterial diarrhoea in animals [16-18].

For all these reasons, the increasing trend in pig production is the use of phytogenic additives which are added to the animal feed. They may improve the production performance of the animals owing to their beneficial effects on the health and weight gain and result in better quality of animal products. These additives are composed of plant parts, spices, aetheric oils and resins. Phytogenic components influence the organoleptic properties of feed, which improve its palatability and consequently may increase feed consumption [19]. They stimulate the production of pancreatic enzymes [20], improve digestion [21], exert antimicrobial effects against various pathogens [22,23], have an antioxidative [24] and anti-inflammatory action [25], and positively influence growth and production performance [26,27].

The present study was conducted to determine the effects of a phytogenic feed additive (PATENTE HERBA ${ }^{\circledR}$ PLUS) on the intestinal histomorphometric characteristics in weaned pigs subclinically naturally infected with L. intracellularis.

\section{MATERIAL AND METHODS}

\section{Phytogenic feed additive}

The experimental substance used was a commercial phytogenic feed additive PATENTE HERBA ${ }^{\circledR}$ PLUS (Patent Co. DOO, Mišićevo, Serbia) containing the extract of Castanea sativa, lysozyme, nicotinamide, and a mixture of an essential oils 
blend (mostly from Thymus vulgaris, Origanum vulgare and Coriandrum sp.). The recipe of the additive is proprietary. An additive was added to the feed in a concentration recommended by the producer $-2 \mathrm{~kg} / \mathrm{t}$ of feed.

\section{Animals, housing and treatments}

The study was carried out on a commercial pig farm. A total of 12 seven-week-old weaned pigs (Yorkshire $\times$ Landrace $\times$ Duroc) from a commercial herd were involved. The farm had a previous record of PE outbreaks, including the clinical and subclinical form of the disease confirmed by real-time PCR assay. The presence of any other disease on the farm was not confirmed by routine laboratory tests.

Two experimental groups of 6 weaned pigs were used in this study. All the animals were naturally infected with $L$. intracellularis, which was confirmed by real-time PCR test as previously described by Richter et al. [28]. One group (6 pigs) was the treatment group and another ( 6 pigs) was the control group. The treatment group (TG) received the feed supplemented with PATENTE HERBA ${ }^{\circledR}$ PLUS, whilst the control group (CG) was fed with the same feed, but without any additives. The pigs had free access to feed and water. Each individual pig was housed in a separate pan. The accommodation and hygiene conditions were the same for all animals throughout the experiment. The experimental feeding lasted for 28 days.

The treatments and procedures on the animals were approved by the Ethical Committee of the University of Belgrade - Faculty of Veterinary Medicine, and the Ministry of Agriculture and Environmental Protection of the Republic of Serbia (Decision no. 323-07-4087/2016-05/1, issued on 9 May 2016), in compliance with the Serbian Animal Welfare Protection Law and the Directive on the Protection of Animals used for Scientific Purposes (No. 2010/63/EU).

\section{Sample preparation for histological assessment}

Samples of the small intestine were obtained within 20 minutes after slaughter in an abattoir. A $10 \mathrm{~cm}$ long portion of the distal ileum, proximal to the ileocecal valve, was collected from each animal and fixed in 10\% neutral formalin for 48-72 h. The tissue samples were processed in an automatic tissue processor (Leica Biosystems, Nussloch, Germany) - dehydrated and embedded in paraffin wax. Sections were cut at a thickness of $4 \mu \mathrm{m}$, and stained with haematoxylin and eosin for histopathology. Standard glass microscope slides were used for mounting.

\section{Histomorphometry}

To evaluate the differences in villous and crypt morphometry in the treatment group and the control intestinal sections the average crypt depth, villous height, and villous width were measured and assessed. At light microscopy $(10 \times$ objective lens $)$, intact and 10 well-oriented villi and crypts from each intestinal section of each animal were randomly selected for measurement. The villus length was measured from the 
villus-crypt junction to the villus tip and the crypt depth from the crypt base to the villus-crypt junction. The same villus and crypt columns were used to determine the number of goblet cells which was expressed per 100 enterocytes. Villus / crypt ratio was calculated by dividing the villus height by crypt depth. Apparent villus surface area was calculated from the villus height and width [29]. The samples were evaluated and measurements were performed with Olympus BX51 microscope with a colour digital CCD camera (Color View III, Olympus) connected to a computerized image analysis system (Olympus Cell B, Olympus, Japan).

\section{Statistical analysis}

The statistical analysis of the obtained results was conducted using the GraphPad Prism version 6.00 software for Windows (GraphPad Software, San Diego, CA, USA, www.graphpad.com). Statistical parameters were given as means plus/minus standard deviations $(\mathrm{X} \pm \mathrm{SD})$. The results obtained for the control and treatment group were compared by using unpaired Student's test to assess the significance of differences. The differences were considered statistically significant if $\mathrm{P}<0.05$.

\section{RESULTS}

\section{Microscopic changes}

In the group of infected pigs which were not treated with the phytogenic additive (the control group), in the ileum samples, the architecture of the mucosa was properly organized in the intestinal crypts and villi. On the surface, there was some exudate with low quantities of mucus and desquamated cells (Figure 1a). In the mucosa, the goblet cell division rate was moderate, and a proliferation of epithelium cells of the Lieberkühn crypts with pronounced mitosis was seen (Figure 1b). Moderate hyperplasia of the lymphatic tissues of the Peyer's patches was present (Figure 1c). The lamina propria mucosae was oedematous in some places, and its blood vessels hyperaemic. In two pigs the lamina propria was slightly infiltrated with lymphocytes and eosinophilic granulocytes (Figure 1d).

In tissue samples of infected pigs treated with the phytogenic additive a mild lymphatic tissue hyperplasia was noticed in Peyer's patches, whilst individual lymphocytes were affected by apoptotic processes (Figure 2a). Lamina propria was heavily infiltrated with lymphocytes and a small number of eosinophilic granulocytes (Figure 2b). The mitotic division of the goblet cells (Figure 2c) and the proliferation of the epithelium cells of Lieberkühn crypts (Figure $2 \mathrm{~d}$ ) were less intense in comparison with those in the control group.

\section{Histological morphometry}

The results of the morphometric measurements are summarized in Table 1. Hystometric analysis showed that the crypts were significantly shorter $(\mathrm{P}<0.05)$, and the villus height-to-crypt depth ratio $(\mathrm{P}<0.05)$ significantly higher in the treated group 
of pigs than in the one that did not receive the additive in feed. The treatment did not affect any of the other parameters which were assessed: villus height, width and surface area, and the number of goblet cells per a hundred enterocytes.

Table 1. Effects of feed supplementation with additive on intestinal morphometric parameters

\begin{tabular}{lccc}
\hline \multirow{2}{*}{ Item } & \multicolumn{2}{c}{ Experimental group } & \multirow{2}{*}{ Pontrol } \\
\cline { 2 - 3 } & \multicolumn{2}{c}{$(\overline{\boldsymbol{X}} \pm \mathbf{S d})$} & Treatment \\
\cline { 2 - 3 } & $529.30 \pm 115.20$ & $571.20 \pm 127.20$ & 0.0607 \\
\hline Villus height $(\mu \mathrm{m})$ & $187.80 \pm 48.69$ & $172.60 \pm 42.56$ & 0.0728 \\
Villus width $(\mu \mathrm{m})$ & $216.20 \pm 68.95^{\mathrm{a}}$ & $192.10 \pm 47.80^{\mathrm{b}}$ & 0.0284 \\
Crypt depth $(\mu \mathrm{m})$ & $2.72 \pm 0.84^{\mathrm{a}}$ & $3.16 \pm 0.79^{\mathrm{b}}$ & 0.0040 \\
Villus height/crypt depth ratio & $0.099 \pm 0.034$ & $0.098 \pm 0.030$ & 0.7676 \\
Villus surface area $\left(\mathrm{mm}^{2}\right)$ & $19.17 \pm 3.19$ & $23.60 \pm 3.93$ & 0.0575 \\
\hline Goblet cells/100 enterocytes & & \\
\hline
\end{tabular}

${ }^{a-b}$ Different lower-case superscript letters in the same row indicate significant differences $(\mathrm{P}<0.05)$ between the groups
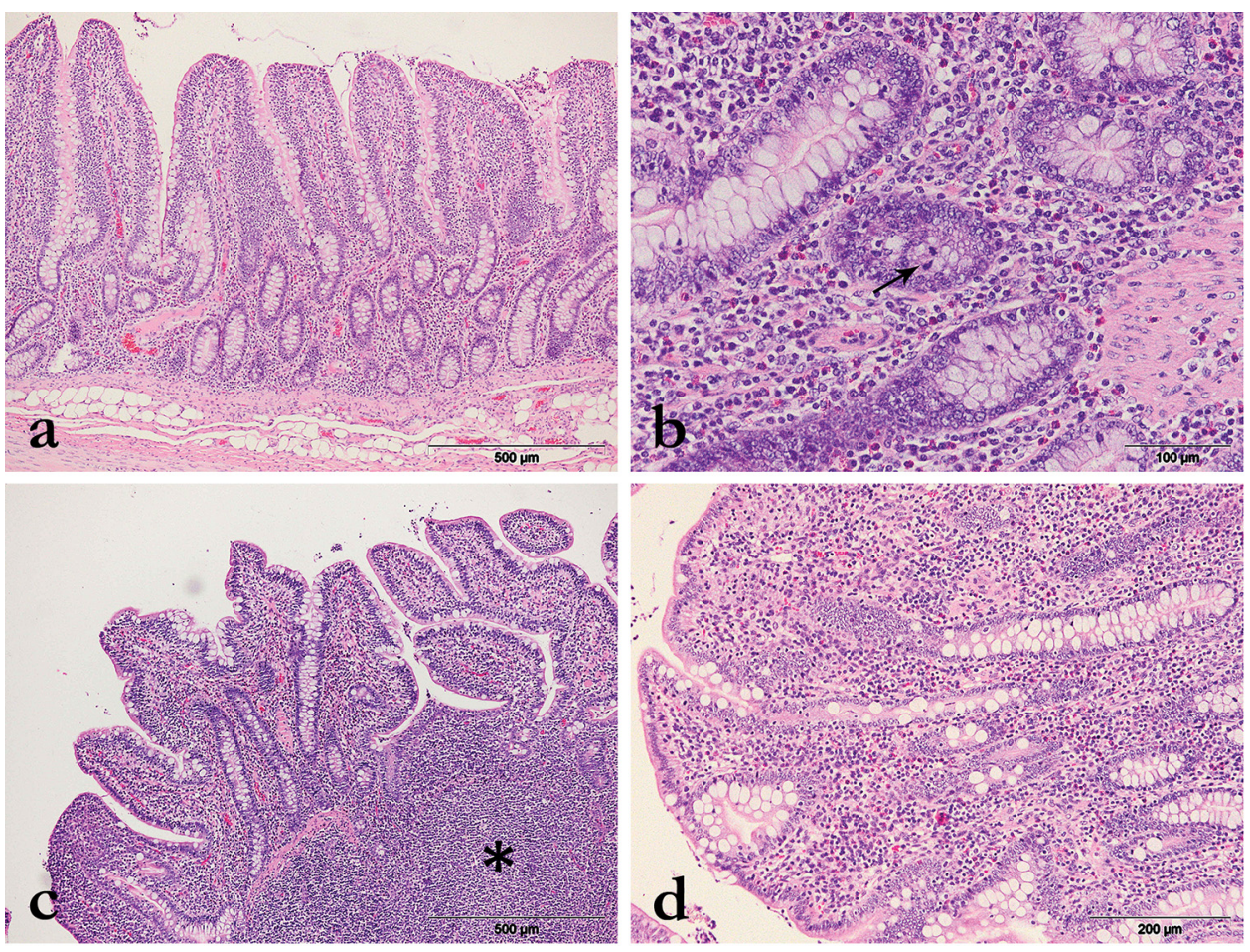

Figure 1. Microscopic changes in the ileum of the pigs in the control group, HE. a) The image of the intestinal villi and the crypts, exudate rich in mucus and desquamated cells on the mucosal surface; b) Proliferation of Lieberkühn crypt cells with noticeable mitoses (arrow); c) Hyperplasia of the lymphatic tissue of the Peyer's patches (asterisk); d) Lamina propria infiltrated with lymphocytes and eosinophilic granulocytes. 

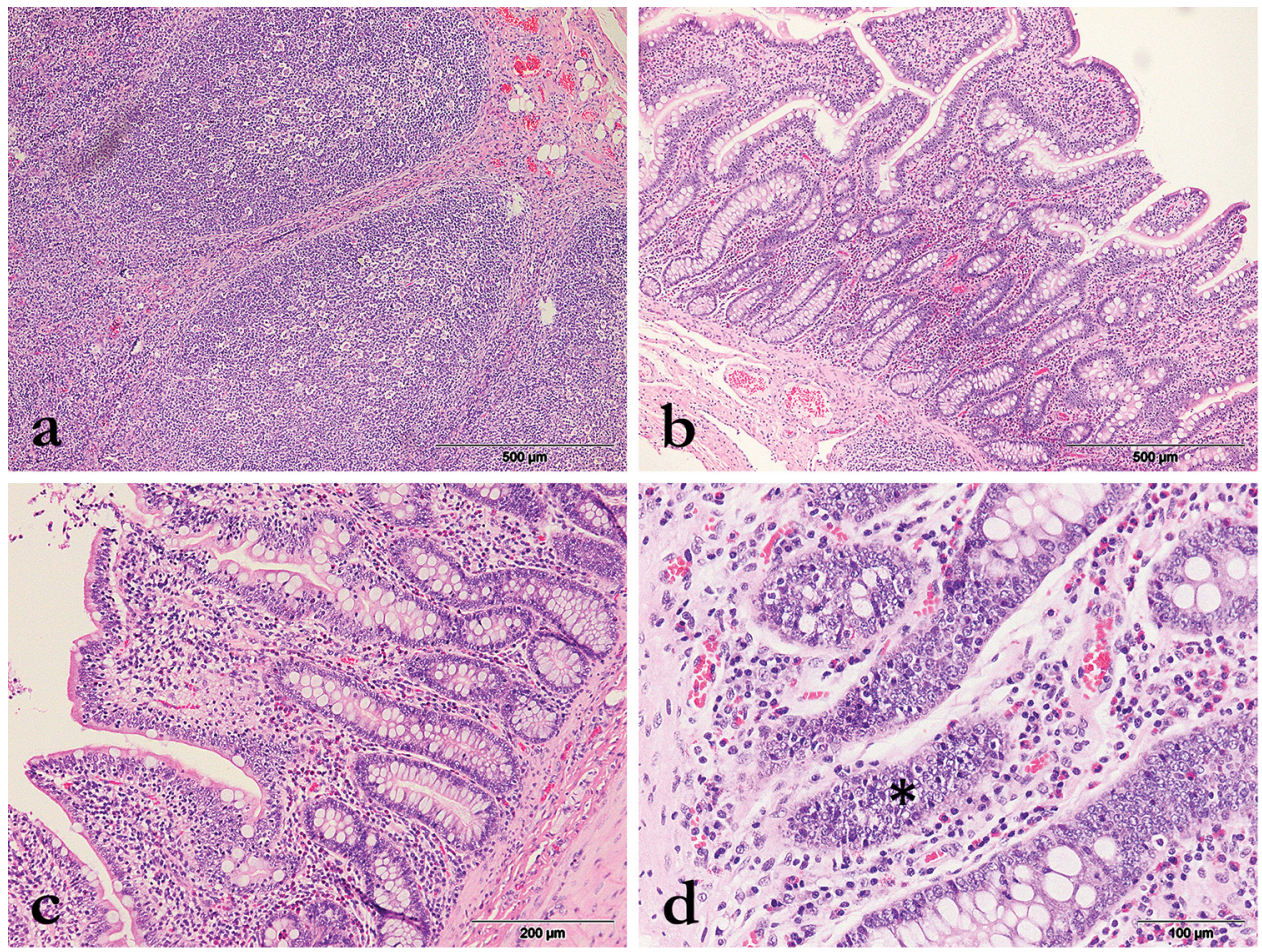

Figure 2. Microscopic changes in the ileum of the pigs treated with the phytogenic additive, HE. a) Hyperplasia of the lymphatic tissues of the Payer's patches with a pronounced halo around individual apoptotic lymphocytes; b) Infiltration of the lamina propria with lymphocytes and eosinophilic granulocytes; c) Proliferation of goblet cells in the intestinal mucosa; d) Proliferation of the epithelium cells of the Lieberkühn crypts (asterisk).

\section{DISCUSSION}

The period of weaning and the beginning of non-maternal feeding is considered to be a highly stressogenic time for the piglets owing to the change in diet, separation from the mother and the transport to different ambient conditions [30]. This is also associated with bacterial intestinal infections, such as enteritis caused by $L$. intracellularis [31].

In the current research, supplementation with a phytogenic additive exerted certain effects on the histological morphology of the ileum in weaned pigs infected by $L$. intracellularis. Changes in the intestinal morphology result in disturbances in the nutrient digestion and absorption [30], as it has been proven that a favourable villus / crypt ratio improves the digestibility of feed components [32]. 
The positive effect of the additive tested in this experiment resulted in higher villusto-crypt ratio and the decrease in the average intestinal crypt depth, in comparison to the control group pigs which were not given any additive in the feed.

The average depth of the intestinal crypts in the ileum was significantly reduced in the pigs treated with the supplement in comparison to the control. Shallow intestinal crypts and high villi are the indicators of the gut health $[33,34]$. In this research, the villus-to-crypt ratio was higher in pigs which were provided with the phytobiotic supplement, which is a result in line with some other reported previously [35-37].

It is shown that antibiotics and various feed additives (prebiotics and probiotics) increase villus length with a concomitant decrease of the crypt depth [38] which is in accordance with the results of the present study. Besides having some other functions, the crypts are the source of multipotent stem cells that give rise to the cells of the villi. High villus length-to-crypt depth ratio as a result of shallower crypt depths implies to decreased cellular turnover and redirection of energy to be utilized for growth [38].

The length of the villi did not differ significantly between the pig groups, which is in line with the findings published by Namkung et al. [39] and Nofrarias et al. [37]. However, in the research conducted by Kroismair et al. [40], there was a tendency of shortening of the villi in the jejunum and ileum influenced by the addition of essential oils.

The numbers of goblet cells estimated in relation to a hundred epithelial cells were similar in both the treated and control pigs, and similar to those reported by Nofrarias et al. [37]. By contrast, it is characteristic of the advanced stages of proliferative enteropathy that there is a reduction in the number and even the absolute absence of goblet cells [41].

The villus surface area did not differ significantly between the two groups of pigs, which is in compliance with the results previously published by other authors [42].

Previous research conducted by Papatsiros et al. [16] and Draskovic et al. [17] suggested that phytogenic additives may be a sound alternative solution to the control of the bacterial infection in pigs caused by L. intracellularis. In addition, the results of the present study indicate that the supplementation of feed additives containing a mixture of different plant extracts and essential oils could improve the histomorphometric parameters of the ileum and consequently enhance the absorption and growth performance of the pigs. Having in mind all the threats posed by antimicrobial resistance and the beneficial effects of the tested phytogenic additive in this study, it can be considered that this supplementation gives the possibility of the replacement of antibiotics used in livestock production.

\section{Acknowledgements}

This study was supported by the Ministry of Education, Science and Technological Development of the Republic of Serbia (Grant No. III46002 awarded for the project 
led by professor Zoran Stanimirovic), and the Innovation Fund of the Republic of Serbia (an Innovation voucher No 138).

\section{Authors' contributions}

DV and SZ designed the investigation, interpreted the results and wrote the manuscript. GM performed the statistical analysis and analyzed the data. BNJ helped performed analysis and co-wrote the paper. TR and TV made substantial contributions to the interpretation of data and writing the manuscript. KV carried out a histomorphometry analysis and evaluated histological preparations. All authors have approved the final version of the manuscript.

\section{Declaration of conflicting interests}

Patent Co. partly funded this study and one of the co-authors (Jasna BosnjakNeumuller) is employee of Patent Co. Other authors declared no potential conflicts of interest with respect to the research, authorship, and/or publication of this article.

\section{REFERENCES}

1. Lawson GH, Gebhart CJ: Proliferative enteropathy. J Comp Pathol 2000, 122:77-100.

2. Kroll JJ, Roof MB, Hoffman LJ, Dickson JS, Harris DH: Proliferative enteropathy: a global enteric disease of pigs caused by Lawsonia intracellularis. Anim Health Res Rev 2005, 6:173197.

3. McOrist S: Defining the full costs of endemic porcine proliferative enteropathy. Vet J 2005, 1:8-9.

4. McOrist S, Smith SH, Green LE: Estimate of direct financial losses due to porcine proliferative enteropathy. Vet Rec 1997, 140:579-81.

5. Veenhuizen MF, Elam TE, Soenksen N: Porcine proliferative enteropathy: diagnosis and impact. Comp Cont Educ Pract 2002, 24:S10-S15.

6. Vannucci FA, Gebhart CJ, McOrist S: Proliferative Enteropathy. Diseases of Swine. 2019, 898-911.

7. Smith DG, Lawson GH: Lawsonia intracellularis: getting inside the pathogenesis of proliferative enteropathy. Vet Microbiol 2001, 82:331-345.

8. Brandt D, Kaim U, Baumgärtner W, Wendt M: Evaluation of Lawsonia intracellularis infection in a group of pigs in a subclinically affected herd from weaning to slaughter. Vet Microbiol 2010, 146:361-365.

9. Paradis MA, Gebhart CJ, Toole D, Vessie G, Winkelman NL, Bauer SA, Wilson JB, McClure CA: Subclinical ileitis: Diagnostic and performance parameters in a multi-dose mucosal homogenate challenge model. J Swine Health Prod 2012, 20:137-141.

10. Collins A, Love RJ, Pozo J, Smith SH, McOrist S: Studies on the ex vivo survival of Lawsonia intracellularis. J Swine Health Prod 2000, 8:211-215.

11. McOrist S, Blunt R, Gebhart CJ: Pig-associated Lawsonia intracellularis in various on-farm dipterous fly stages. J Swine Health Prod 2011, 19:277-283. 
12. Gabardo MD, Sato JP, Daniel AG, Andrade MR, Pereira CE, Rezende TP, Otoni LV, Rezende LA, Guedes RM: Evaluation of the involvement of mice (Mus Musculus) in the epidemiology of porcine proliferative enteropathy. Vet Microbiol 2017, 205:75-79.

13. Jacobson M, Fellström C, Jensen-Waern M: Porcine proliferative enteropathy: an important disease with questions remaining to be solved. Vet J 2010, 184:264-268.

14. Li J: Current status and prospects for in-feed antibiotics in the different stages of pork production-A review. Asian Austral J Anim 2017, 30:1667-1673.

15. Aarestrup FM: Association between the consumption of antimicrobial agents in animal husbandry and the occurrence of resistant bacteria among food animals. Int J Antimicrob Ag 1999, 12:279-285.

16. Papatsiros VG, Tzika ED, Papaioannou DS, Kyriakis SC, Tassis PD, Kyriakis CS: Effect of Origanum vulgaris and Allium sativum extracts for the control of proliferative enteropathy in weaning pigs. Pol J Vet Sci 2009, 12:407-414.

17. Draskovic V, Bosnjak-Neumuller J, Vasiljevic M, Petrujkic B, Aleksic N, Kukolj V, Stanimirovic Z: Influence of phytogenic feed additive on Lawsonia intracellularis infection in pigs. Prev Vet Med 2018, 151:46-51.

18. Delić N, Drasković V, Stevanović J, Savić B, Lakić N, Bosnjak-Neumuller J, Stanimirović $Z$ : The efficacy of two phytogenic feed additives in the control of swine dysentery. Acta Vet-Beograd 2018, 68:178-189.

19. Windisch W, Schedle K, Plitzner C, Kroismayr A: Use of phytogenic products as feed additives for swine and poultry. J Anim Sci 2008, 86(suppl_14):E140-E148.

20. Platel K, Srinivasan K: Digestive stimulant action of spices: a myth or reality?. Indian J Med Res 2004, 119:167-179.

21. Amad AA, Männer K, Wendler KR, Neumann K, Zentek J: Effects of a phytogenic feed additive on growth performance and ileal nutrient digestibility in broiler chickens. Poultry Sci 2011, 90:2811-2816.

22. Jugl-Chizzola M, Spergser J, Schilcher F, Novak J, Bucher A, Gabler C, Hagmüller W, ZitterlEglseer K: Effects of Thymus vulgaris $L$. as feed additive in piglets and against haemolytic E. coli in vitro. Berl Munch Tierarztl 2005, 118:495-501.

23. Burt S: Essential oils: their antibacterial properties and potential applications in foods-a review. Int J Food Microbiol 2004, 94:223-253.

24. Mueller K, Blum NM, Kluge H, Mueller AS: Influence of broccoli extract and various essential oils on performance and expression of xenobiotic-and antioxidant enzymes in broiler chickens. Brit J Nutr 2012, 108:588-602.

25. Kara M, Uslu S, Demirci F, Temel HE, Baydemir C: Supplemental carvacrol can reduce the severity of inflammation by influencing the production of mediators of inflammation. Inflammation. 2015, 38:1020-1027.

26. Kroismayr A, Sehm J, Pfaffl M, Plitzner C, Foissy H, Ettle T, Mayer H, Schreiner M, Windisch W: Effects of essential oils or Avilamycin on gut microbiology and blood parameters of weaned piglets. Czech J Anim Sci 2008, 53:377-387.

27. Frankič T, Voljč M, Salobir J, Rezar V: Use of herbs and spices and their extracts in animal nutrition. Acta Agric Slov 2009, 94:95-102.

28. Richter B, Ladinig A, Nedorost N, Herbert W: A TaqMan quantitative polymerase chain reaction assay for the detection of Lawsonia intracellularis in fecal and tissue samples from pigs. J Vet Diagn Invest 2010, 22:70-73. 
29. Van Zuidewijn DD, Schillings PH, Wobbes TH, Hendriks T, de Boer HH: Morphometric analysis of the effects of antineoplastic drugs on mucosa of normal ileum and ileal anastomoses in rats. Exp Mol Pathol 1992, 56:96-107.

30. Pluske JR, Hampson DJ, Williams IH: Factors influencing the structure and function of the small intestine in the weaned pig: a review. Livest Prod Sci 1997, 51:215-236.

31. Kroll JJ, Roof MB, McOrist S: Evaluation of protective immunity in pigs following oral administration of an avirulent live vaccine of Lawsonia intracellularis. Am J Vet Res 2004, 65:559-565.

32. Shen YB, Piao XS, Kim SW, Wang L, Liu P, Yoon I, Zhen YG: Effects of yeast culture supplementation on growth performance, intestinal health, and immune response of nursery pigs. J Anim Sci 2009, 87:2614-2624.

33. Qaisrani SN, Moquet PC, Van Krimpen MM, Kwakkel RP, Verstegen MW, Hendriks WH: Protein source and dietary structure influence growth performance, gut morphology, and hindgut fermentation characteristics in broilers. Poultry Sci 2014, 93:3053-3064.

34. Peng QY, Li JD, Li Z, Duan ZY, Wu YP: Effects of dietary supplementation with oregano essential oil on growth performance, carcass traits and jejunal morphology in broiler chickens. Anim Feed Sci Tech 2016, 214:148-153.

35. Manzanilla EG, Nofrarias M, Anguita M, Castillo M, Perez JF, Martin-Orue SM, Kamel C, Gasa J: Effects of butyrate, avilamycin, and a plant extract combination on the intestinal equilibrium of early-weaned pigs. J Anim Sci 2006, 84:2743-2751.

36. Oetting LL, Utiyama CE, Giani PA, Ruiz UD, Miyada VS: Effects of herbal extracts and antimicrobials on apparent digestibility, performance, organs morphometry and intestinal histology of weanling pigs. Rev Bras Zootecn 2006, 35:1389-1397.

37. Nofrarias M, Manzanilla EG, Pujols J, Gibert X, Majo N, Segalés J, Gasa J: Effects of spray-dried porcine plasma and plant extracts on intestinal morphology and on leukocyte cell subsets of weaned pigs. J Anim Sci 2006, 84:2735-2742.

38. Marković R, Šefer D, Krstić M, Petrujkić B: Effect of different growth promoters on broiler performance and gut morphology. Arch Med Vet 2009, 41:163-169.

39. Namkung H, Li J. Gong M, Yu H, Cottrill M, De Lange CF: Impact of feeding blends of organic acids and herbal extracts on growth performance, gut microbiota and digestive function in newly weaned pigs. Can J Anim Sci 2004, 84:697-704.

40. Kroismayr A, Sehm J, Pfaffl MW, Schedle K, Plitzner C, Windisch W: Effects of avilamycin and essential oils on mRNA expression of apoptotic and inflammatory markers and gut morphology of piglets. Czech J Anim Sci 2008, 53:377-387.

41. McOrist S, Gebhart CJ, Bosworth BT: Evaluation of porcine ileum models of enterocyte infection by Lawsonia intracellularis. Can J Vet Res 2006, 70:155-159.

42. Bilić-Šobot D, Kubale V, Škrlep M, Čandek-Potokar M, Prevolnik Povše M, Fazarinc G, Škorjanc D: Effect of hydrolysable tannins on intestinal morphology, proliferation and apoptosis in entire male pigs. Arch Anim Nutr 2016, 70:378-388. 


\section{EFEKTI FITOGENOG ADITIVA NA HISTOMORFOMETRIJSKE KARAKTERISTIKE CREVA KOD ODLUČENE PRASADI SUPKLINIČKI PRIRODNO INFICIRANE BAKTERIJOM}

\section{Lawsonia intracellularis}

DRAŠKOVIĆ Vladimir, STANIMIROVIĆ Zoran, GLIŠIĆ Milica, BOŠNJAK-NEUMULLER Jasna, TEODOROVIĆ Radislava, TEODOROVIĆ Vlado, KUKOLJ Vladimir

Proliferativna enteropatija poznata kao i proliferativni ileitis smatra se jednom od ekonomski najznačajnih bolesti u svinjarskoj proizvodnji širom sveta. Procenjeni gubici po obolelom tovljeniku obično se kreću od 1 do 5 američkih dolara. Uzročnik ovog oboljenja je Lawsonia intracellularis, gram negativna obligatna intracelularna bakterija. Kontrola ovog oboljenja ostvaruje se primenom vakcinacije ili antibiotika. U poslednje vreme sve je češća primena fitogenih aditiva u cilju kontolisanja određenih patoloških stanja digestivnog trakta. Cilj ovog rada bio je da se ustanove efekti fitogenog aditiva na histomorfometrijske karakteristike creva kod odlučenih prasadi supklinički prirodno inficiranih $L$. intracellularis. Histomorfometrijska analiza pokazala je da su kripte bile značajno $(P<0,05)$ pliće, a količnik visine vilusa i dubine kripti značajno veći $(P<0,05)$ u tretiranoj grupi prasadi nego u kontroli. Ovo poboljšanje histoloških parametara creva, koje se smatraju indikatorima njegovog zdravlja, dokaz je pozitivnog efekta ispitivanog aditiva na digestivni sistem svinja. 